\title{
Sustainable Tourism Recommendations: Systematic Literature Review
}

\author{
Retno Santi Sumardi ${ }^{1}$, Anuar Shah Bali Mahomed ${ }^{2}$, Mukhamad Najib $^{3}$ \\ \{shanty_0802@yahoo.com¹, anuar@upm.edu.my², najib@apps.ipb.ac.id $\left.{ }^{3}\right\}$ \\ Faculty of Economics and Management, IPB University, Bogor, Indonesia ${ }^{13}$ \\ School of Business and Economics, Universiti Putra Malaysia, Selangor, Malaysia ${ }^{2}$
}

\begin{abstract}
The importance and the rapid changes in tourism sector has made sustainable tourism is an important to discuss. Sustainability is very important to maintain tourism existence by minimizing negative impacts on the environment and social culture, as well as contributing and providing opportunities for the local economy. Therefore the aims of this literature review is expected to contribute recommendations to obtain sustainability in tourism industry. This paper used PRISMA flow diagram to select the article and critical appraisal with Aveyard observation. This paper were carried out 15 papers were obtained that according to the strategy of sustainability destination tourism topic. There are three factors should be concern in sustainability tourism such as environment, social responsibility and economic. To achieve sustainability tourism, all parties need to be involved in the tourism business.
\end{abstract}

Keywords: destination marketing, marketing startegy, sustainability tourism

\section{Introduction}

Tourism is one of the sector that plays a significant role and offer the biggest GDP for a countries in the world. According to [1], the majority revenue of Indonesia is from tourism about US\$ 20 billion per year, and that revenue as one of the biggest foreign exchange in this country. Meanwhile, tourism in Thailand, Singapore, and Malaysia contribute over than US\$20 billion per year for revenue of those countries. In total, travel and tourism generated US\$ 7.6 trillion (10.2\% of global GDP) and 292 million jobs in 2016, equivalent to 1 in 10 jobs in the global economy [2]. Besides, UNWTO has underlined that in tourism sector is the important sector because could contribute $30 \%$ of world services export, $10 \%$ of global PDB, and has a big contributor to creating a job at least $10 \%$ in the world [3].

However, the changes eternally emerge in all sectors of industries including in this tourism industry. Some changes probably appear in conditions of destinations, tourist perception changes, technology changes, and also 
government policy changes. Those changes could make the instability tourism sector, at the end could affect the total income of a country. Although European countries have the biggest number of international tourists arriving in the world, climate change is in the light as a new challenge [4] and that climate change is given the impact of tourism activities such a calls for a more coordinated approach. Besides, some countries which have good potential in tourism but they did not provide yet all the indicators or motivations that could make tourists come, also they do not know how to increase the consumer satisfaction.

According to [5] the push and pull motivation factors are encourage a person to choose a destination. In marketing literature, satisfaction has a positive influence on post-purchase behavior [6]. Tourist motivation is an essential topic in the international tourism industry [7]. Many criteria make tourists come such as holiday tourism, cultural tourism, social tourism, economic tourism, and political tourism, religious tourism is motivated by religious reason or faith [8].

The importance of tourism and the rapid changes in it has made sustainable tourism development is an important to discuss. According to [9] the purpose of sustainable tourism is to make a balance between protecting the environment, maintaining cultural integrity, establishing social justice and promoting economic benefits, meeting the needs of the host population in terms of improved living standards both in the short and long term and according to [10]; [11] while emphasizing both intergenerational equity and intra-generational equity [9] and in a form that can maintain viability in an area for an indefinite period of time [12],[13]. Based on the gap that has been mentioned aims of this paper are to review recommendations that papers gives and to review the methodology that paper used.

\section{Methodology}

A systematic literature review method was used to examine the state of the art in this topic and identify research gaps and new research directions. In this paper, a systematic literature review applied and used Literatur source from Emerald insight. Using emeral insight because of the world's leading digital first publishers, commisioning, curating and showcasing research that could make a real difference download per year and it is the winner of the best publisher in 2020.

The identification of the studies was carried out through a search on the Scopus database during January 2019, using the following keywords search. 
Keywords are the sustainability of marketing strategy, destination marketing, sustainability tourism. The search results are depicted in a PRISMA flow diagram in Figure 1.

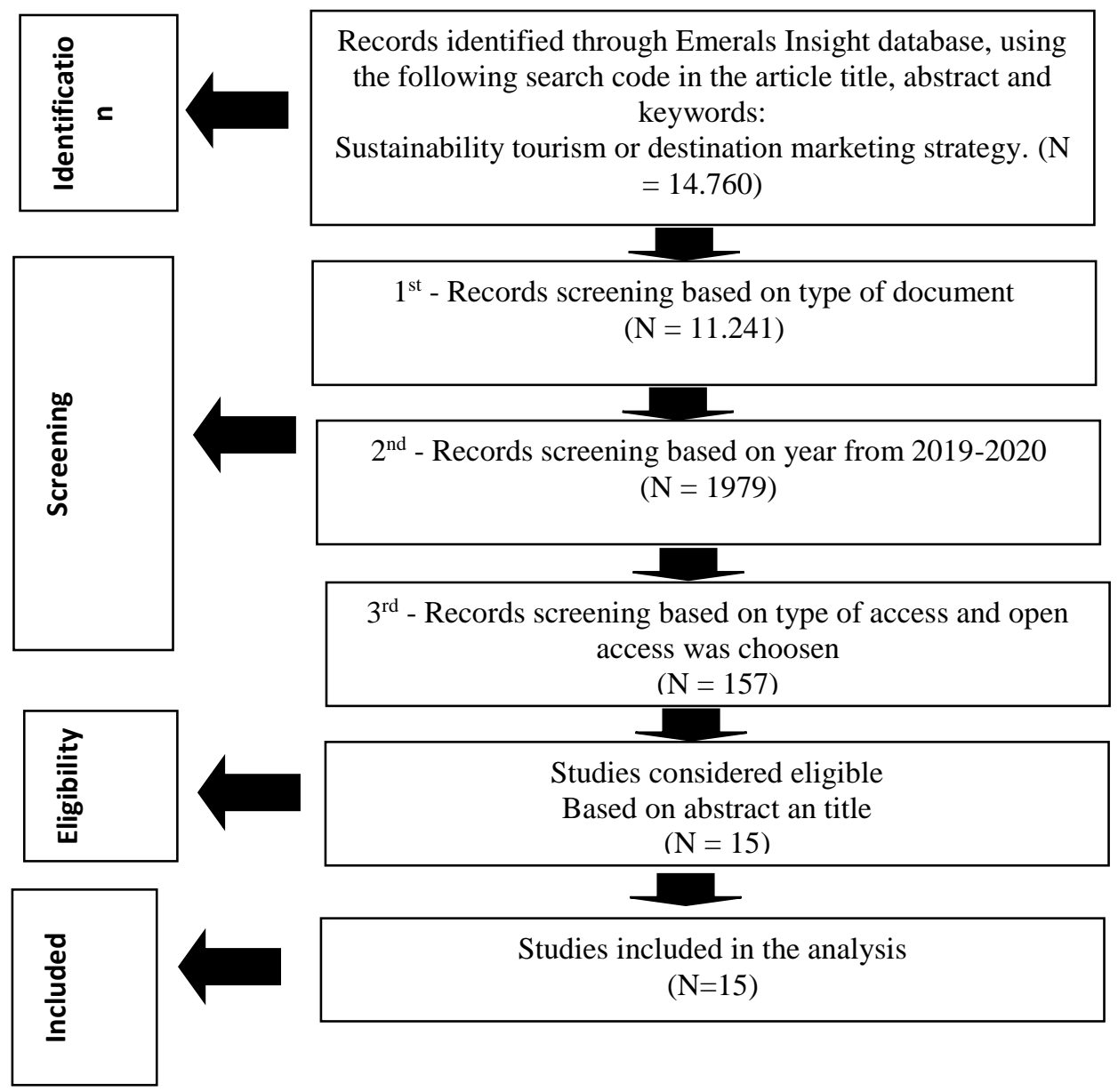

Figure 1. PRISMA flow diagram of the article selection process

Several types of methodology has been used in previous articles. However, the methodology using the 2 stage research protocol is rarely used. Two stages of research protocol are; first to selecting and second defining articles that are analyzed by using PRISMA flow diagram and analysis the content of articles. Prisma flow diagram also commonly use to selected the paper, there are various research used the prisma flow diagram to select the paper [36]; [37]. 


\subsection{Article selection}

Regarding those keywords records 11.241 papers were obtained. Further, only scientific literature such as articles, reviews, research papers were selected. As a consequence of this first screening, the sample of records reduced to 11.241 papers. Further, only documents written in 2019-2020 were selected. 2019-2020 were selected because this year is the biggest distribution that related on that topic. The distribution of paper that according on this topic could be shown in Figure 2. There are many literature that used Prisma Flow diagram to select the paper, but there is no paper that used document in 2019-2020.

Based on this screening 1979 paper records were excluded. The second screening based on access type and open access was selected to analyze. Based on this screening selected 157 papers. The third screening was based on the title and abstract, on this screening was selected 15 papers. Besides the easiest way to obtain a journal, open access also easier to access the paper for a reader.

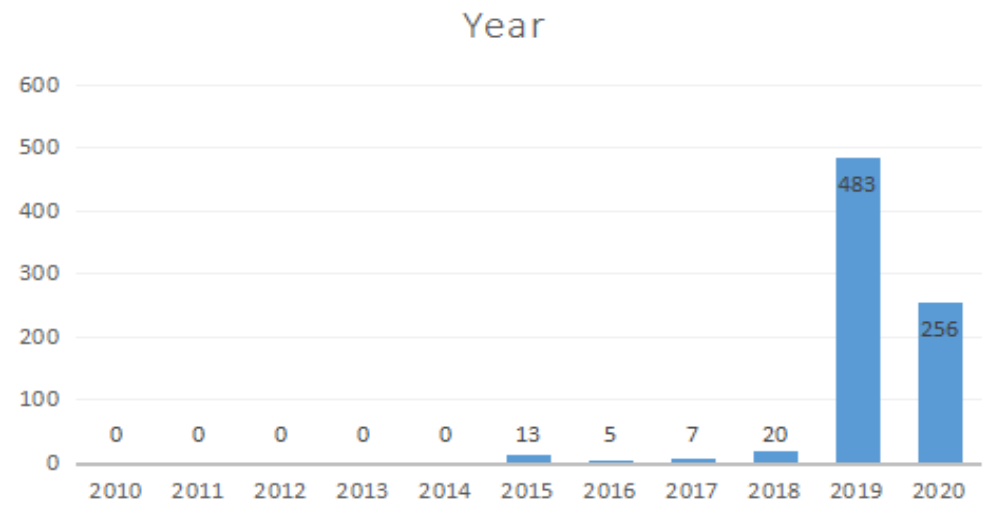

Figure 2. Distribution of publication in 2010-2020

\subsection{Article analysis}

The articles selected in the previous stage were analyzed using two steps. First, a descriptive analysis of the following aspects was carried out: The distribution by journal, scientific area and authorsip also distribution by sustainability tourism context where the study was conducted. As both empirical and theoritical studies were found in a second stage. A Content analysis of the empirical papers was developed to identify as follows: the research methods (data collection, type of data and source), methods analysis, the result obtained concerning obtained sutainability in tourism sector. 


\section{Findings}

The search for the article begins by entering the keywords in the Emerald Insight database, with the keyword search of sustainability tourism "OR" destination marketing strategy. Regarding that search obtained 14.760 papers. That paper is carried out in the screening process based on the type of document. 11.241 papers were selected based on type of document. Journal article has selected to continue the process. Further, the next screening is based on the year, only 2019-2020 will be selected to continue the process. 1979 papers has selected to continue the process. Further screening is based on the type of access, which is open access is selected to be analyze and found 15 papers. The next step is to screening based on the title, abstract, objectives of the study, the corellation of the topic in this paper and only research paper will be selected to continue the process. After various kinds of screening and filtering were carried out 15 papers were obtained that according to the sustainability tourism.

This paper used critical appraisal with Aveyard observation [14]. Critical appraisal is the systematic and thorough process in evaluating the research to decide on trust, value, and relevance in a particular context. In other words, critical analysis is a process of evaluating and interpreting evidence systematically by considering its validity, results, and relevance.

\subsection{Distribution by scientific area and authorship}

According to paper that related with the topic, mostly all author $(98 \%)$ wrote one paper, only Mkwizu has written two papers. There are 7 papers published in journal of tourism futures, 2 papers published in International hospitality review, 2 papers published in journal marketing, and the others published in journal of humanities and journal Asian business and economic studies.

\subsection{Data collection and analysis methods}

According to Table 1, Asia and Europe are the favorite countries for collecting data, followed by middle east, Africa and small island. There are 7 papers were used quantitative methods with structural equation modelling and SPSS analysis, 5 papers are conceptual paper, 2 papers used both quantitative or qualitative methods. While, only one paper used qualitative methods. According to [35] quantitative methods has several benefits: quantitative methods could obtain good of accuracy data, could examine the question about validity of the knowledge and the theories. 
Table 1. Research methodology, research place and type of journal

\begin{tabular}{|c|c|c|}
\hline \multicolumn{2}{|c|}{ Criteria } & Author \\
\hline \multirow{5}{*}{ Research place } & Eropa & {$[24],[25],[20],[18]$} \\
\hline & Asia & {$[27],[30],[34],[19]$} \\
\hline & Middle east & [17] \\
\hline & Asia pacific & [32] \\
\hline & Afrika & [28], [31] \\
\hline \multirow{4}{*}{ Research methodology } & Quantitative & {$[27],[30],[28],[34],[20],[17],[18],[32],[19]$} \\
\hline & Qualitative & {$[24],[18],[19]$} \\
\hline & Literature review & {$[31],[33]$} \\
\hline & conceptual paper & {$[25],[23],[26]$} \\
\hline \multirow{13}{*}{ Name of Journal } & $\begin{array}{l}\text { Journal of tourism } \\
\text { futures }\end{array}$ & {$[27],[24],[25],[33],[17],[18],[32]$} \\
\hline & Journal Asia & [30] \\
\hline & $\begin{array}{l}\text { Pacific journal of } \\
\text { innovation }\end{array}$ & \\
\hline & Journal & {$[28],[31]$} \\
\hline & $\begin{array}{l}\text { International } \\
\text { hospitality review }\end{array}$ & \\
\hline & Journal social & {$[23]$} \\
\hline & responsibility & \\
\hline & $\begin{array}{lr}\text { Journal of } \\
\text { humanities and }\end{array}$ & [26] \\
\hline & $\begin{array}{l}\text { applied social } \\
\text { science }\end{array}$ & \\
\hline & $\begin{array}{l}\text { Journal of } \\
\text { marketing }\end{array}$ & [34], [20] \\
\hline & Journal of Asian & [19] \\
\hline & Business and & \\
\hline & Economic studies & \\
\hline
\end{tabular}

\subsection{Sustainability in tourism sector}

In tourism, there is a very wide range of changes, such as in weather changes, changes in consumer perceptions, changes in a more modern lifestyle. So this is something that is very challenging and has to be considered by carrying out various good collaborations between tourism business owners, business people who support tourism such as hotels manager, restaurants manager, the government, and even the community must be involved in this case regarding the handling of posibility of changes that occur, so the failure of tourism business will not happen. 
Besides, there are negative impacts caused by tourism. In the economic field, the negative impact that will be obtained such as there will be more non-local labor, which will increase competition with residents, and the scarcity of some needs for certain goods. Based on the socio-cultural impact, which will increase population density and significant demographic changes in a place. Meanwhile, the negative impact on the environment will destroy natural and historical resources due to uncontrolled tourism development, and also the reduction in open space due to uncontrolled construction.

The changes in tourism conditions have to bring all the researcher's concerns on how to make sustainability in tourism. Sustainability is the most important factor for the success of any tourism destination and the tourism industry as a whole. Sustainability is a way to maintain tourism existence by minimizing negative impacts on the environment and social culture, as well as contributing and providing opportunities for the local economy.

Findings of papers could be seen in Table II. According to [15] stated that sustainable tourism has played an important role in identifying ways to secure positive benefit as well as the established approaches of regulation and development control. According to [16] stated that sustainability means that tourism is designed in a way as to provide assurance for the sustainability of natural and cultural resources used as attractions, the sustainability of community support and the sustainability of tourists' desire to visit the tourism destination. In other words, the activity of tourism could fulfill all parties needs without sacrifice the environment and future generation importance. [17] There are 3 indicators of sustainability tourism that need to be our concern are environment, sosiocultural and economic.

Table 2. Finding of papers

\begin{tabular}{|c|c|c|}
\hline No & Author & Findings \\
\hline 1 & {$[18]$} & $\begin{array}{l}\text { Nature is one of reason why tourists want to come to tourism destination } \\
\text { and one of strategy is to offer green activities }\end{array}$ \\
\hline 2 & {$[32]$} & $\begin{array}{l}\text { The concept of green tourism such as provide green transport, give } \\
\text { biosphile bottle and nature-friendly amenities }\end{array}$ \\
\hline 3 & [20] & Environmental CSR image has a direct effect on consumer trust \\
\hline 4 & [23] & $\begin{array}{l}\text { Social responsibility concept should be incorporated into tourism } \\
\text { management techniques and and apparatus to facilitate the integration of } \\
\text { tourism market activities }\end{array}$ \\
\hline 5 & [19] & $\begin{array}{l}\text { To make sustainable in the tourism business is to determine the consumer } \\
\text { satisfaction. Attraction with nature, nature-based activities, unpollated } \\
\text { environtment and the attitude and competence of staff at ecotourism site. }\end{array}$ \\
\hline 6 & {$[33]$} & $\begin{array}{l}\text { ICT has a potential fundamentally change the nature of tourism and } \\
\text { business tourism. }\end{array}$ \\
\hline 7 & [27] & Build brand strategy could bringing sustainability in hospitality business. \\
\hline
\end{tabular}




\begin{tabular}{|c|c|c|}
\hline No & Author & Findings \\
\hline 8 & [34] & $\begin{array}{l}\text { The environtmental CSR activities to keep and to mantain long-term } \\
\text { relationship with customers. The CSR activities that related to the } \\
\text { invirontment includes categories such as pollution prevention, green } \\
\text { production/services and energy conservation. }\end{array}$ \\
\hline 9 & [30] & $\begin{array}{l}\text { One of the way to make sustainable in tourism industry is to increase } \\
\text { consumer satisfaction. Consumer satisfaction could achieve with improve } \\
\text { their product and services based on religious. }\end{array}$ \\
\hline 10 & & sustainability in tourism with knowing motivation of tourism. \\
\hline 11 & & $\begin{array}{l}\text { Tourism as a part of a systematic growth strategy, has the real and } \\
\text { affordable potential to contribute significantly to the environtmental, } \\
\text { social cultural and economic growth }\end{array}$ \\
\hline 12 & [24] & $\begin{array}{l}\text { New cultural tourists could increase demand access to locals because } \\
\text { locals life could showing equal social status for all relevant groups }\end{array}$ \\
\hline 13 & [25] & $\begin{array}{l}\text { The uniqeness of historical buildings and their role in forming } \\
\text { extraordinary experience escapes provides a supply of destinations and } \\
\text { offer aesthetic experience that can not be replicated by a newly built } \\
\text { attraction or hotel. }\end{array}$ \\
\hline 14 & [31] & $\begin{array}{l}\text { Mobile advertising could act as a digital marketing trends and assist to } \\
\text { increase international tourism as well as strategy of innovation of } \\
\text { marketing promotion. }\end{array}$ \\
\hline 15 & [26] & $\begin{array}{l}\text { Sustainable tourism as a relatively new concept refers to tourism that } \\
\text { attemps to minimize environtmental impacts and sociocultural changes } \\
\text { and also creating unique economic opportunity for local community }\end{array}$ \\
\hline
\end{tabular}

According to the research of [18] stated that sustainability in tourism could obtained by maintaining and offering activities related to nature (green activities) will increase and attract tourists to come to these tourist attractions. Apart from providing tourism in the form of eco-tourism, such as activities based on nature, unpolluted environment, the attitude and competence of staff at ecotourism sites [19], not only that but also could reflect on providing the enviroment hospitality [20]. The other several factors, namely having certificate of eco-friendly hotels [20] besides other environmental factors that can affect is a factor of a safe and comfortable situation [21], however not only cleanliness is an environmental factor but also security and safety [22].

[23] The essential relation between the social responsibility concept in the tourism industry and sustainability is clearly illustrated there by the interconnection of the mission, basis, perceptions, reflections, and determinants of the social responsibility concept in the tourism sector, as well as by the determination of the influencing factors to integrated the general education system and especially into tourism training and education, the social responsibility concept should be incorporated into tourism management techniques and apparatus to facilitate to the common activities of the tourism market, for example is to build Coorporate Social Responsibility or CSR [20] 
activities that related to nature. In the concept of sosiocultural not only build CSR but also there are several supporting factors to obtain sustainability in tourism [24] also stated that offering the uniqueness of the culture of the area of origin will be a special attraction for tourists, offer historic building [25], nation branding with showing their cultural heritage [26], and build a cultural center [24].

The positive impact that can be generated from tourism in the economic sector is an increase in foreign exchange earnings, creating and new business opportunities for employers and workers, helping to increase regional income, increasing local people's income, as well as developing local markets. One of the ways to improve the economy in tourism is by building a brand strategy. Brand strategy is one of the marketing strategies for bringing sustainability in the business including in the tourism business. [27] Perceived quality and brand interaction, forms brand trust and trust is the key factor in establishing emotional (affective) commitment between the customer and the hospitality brand. Tourism development with knowing motivation and their satisfaction. To know consumer motivation by looking at the demographic factors, namely age, gender, and number of families [28].

[19] increasing consumer satisfaction by developing consumer emotions by forming eco-friendly tourism, and also following the statement by [29] to control and altering consumer attitude is a key for marketing strategy. So that marketers must be able to build a positive attitude in the minds of consumers to attract tourists. In addition to increase the interest of tourism according to [30] is to improve their quality products and their services based on Islamic perspective. Beside that, sustainable promotion is also very important for the creation of sustainable tourism. According to [31] the effective promotion strategy is by using social media such as Facebook subscribers, creating creative content, and mobile advertising, [26] do the nation branding, [32] ICT (Information Communication Technology).

\section{Conclusion}

To achieve sustainability tourism, all parties need to be involved in the tourism business. They are who involved are a businessman in the tourism sector, workers in the tourism sector, government, all stakeholders also the community/society has to be involved to increase this business. The ways that can be done include: 
1. To create stability in the economy and the tourism environment, the government must create a strict environmental regulations, and create easy regulations, also support nature activities.

2. Hospitality managers should design strategies to raise the perception of the green-related features of environmentally certified companies. Hoteliers should improve their hotel's environmental CSR image and increase the level of consumer trust. Hotel managers should place more investment in socially responsible initiatives, especially environment activities, as consumers tend to reward and support a company, which is perceived as socially responsible through the development of loyalty towards them. Also, the hotel manager should aware of the relative importance of all elements concerning customer loyalty to know their preferences and particular roles on the individual components,

3. Tourism management has to create an integrated education system especially to create training and sharing knowledge about tourism and create a facility in activities among tourism market dan tourism management,

4. Stakeholders in the tourism sector should consider digital marketing like social media marketing, creative content and mobile advertising as digital marketing trends in tourism marketing,

5. The marketers should focus on enhancing customer emotions. Marketers could get their emotions to get the reference of the potential customers and existing customers by creating a friendly environment,

6. Tourism companies can enhance their brand image by improving the products and services based on a religious perspective that can lead to an increase in consumer satisfaction. Offer the uniqueness of culture and historic buildings. In addition, destination managers need to use of the existing attractions such as mountains, beaches, national parks, and game reserves to position the country as an adventurous destination. Destination managers should advertise tourist activities such as boat cruising, shopping, swimming, as well as beach sports activities for this group.

\section{Limitations of paper}

This study contained several limitations. First this study limited in literature review only, certain type of document, certain year, certain search engine and scope as well. As an extension of this study, future research should test many kind of factors to make sustainable in tourism sector specific in quantitative or qualitative methods. 


\section{References}

[1] [KEMENPAR] Kementerian Pariwisata. 2015. Laporan akhir kajian pengembangan wisata syariah. [diunduh 2018 Feb 7]. Tersedia Pengembangan Wisata Syariah.pdf. pada:http://www.kemenpar.go.id/userfiles/2015 Kajian

[2] World Travel and Tourism Council. 2017. Travel and tourism economic impact 2017 Malaysia.https://www.wttc.org/-/med ia/files/reports/economic-impact-rese arch/countries-2017/malaysia2017.pd f [diunduh pada Januari 2019].

[3] Tim Riset CNBC Indonesia. 2019. Ini negara dengan cuan wisata terbesar.DimanaIndonesia?.https://w ww.cnbcindonesia.com/news/201903 03142653-4-58613/ini-negara-denga n-cuan-wisata-terbesar-di-mana-indo nesia/2

[4] Roca et al.2020. Back to the future: Challenges of European tourism of tomorrow. Journal of tourism futures. DOI 10.1108/JTF-10-2019-0114.

[5] Zhang Y and Peng Y. 2014. Understanding travel motivation of chinese tourists visiting cairns Australia. Journal of hospitality and tourism management. 21:2144-2153

[6] Alegre J and cladera M. 2008. Analysing the effect of satisfaction and previous visits on tourists intentions to return. European Journal of Marketing. Vol. 43 No. 5/6. pp. 670-685.DOI $10.1108 / 03090560910946990$

[7] Caber, M., \& Albayrak, T. (2016). Push or pull: Identifying rock climbing tourists' motivations. Tourism Management, 55, 74-84.

[8] Laderlah, S., Rahman, A.S., Awang, K., \& Man, Y. (2011). A Study on Islamic tourism: A Malaysian experience. 2nd International Conference on Humanities, Historical and Social Sciences IPEDR vol. 17, IACSIT Press, Singapore.

[9] Liu, C. H., Tzeng, G. H., Lee, M. H., \& Lee, P. Y. (2013). Improving metro-airport connection service for tourism development: Using hybrid MCDM models. Tourism Management Perspectives, 6, 95- 107.

[10] Mitchell, M., \& Hall, D. (2005). Rural tourism as sustain-able business: Key themes and issues. In D. Hall, I. Kirkpatrick, \& M. Mitchell (Eds.), Rural tourism and sustainable business (pp. 3-16). Tonawanda, NY: Channel View Publications.

[11] Swarbrooke, J., \& Horner, S. (2004). Consumer behavior in tourism. Burlington, MA: Butterworth-Heinemann.

[12] Butler, R. W. (1993). Tourism - An evolutionary perspective. In J. G. Nelson, R. W. Butler, \& G. Wall (Eds.), Tourism and sustainable development: Monitoring, planning, managing (pp. 27-44). Waterloo: University of Waterloo (Department of Geography Publication 37).

[13] Butler, R. W. (1999). Sustainable tourism: A state-of the-art review. Tourism Geographies, 1, $7-25$

[14] Aveyard, H. (2014). Doing aLiterature Review in Health and Social Care. A pratical guide second editon. New York: McGraw Hill Education

[15] Bramwell, B., \& Lane, B. (2012). Towards innovation in sustainable tourism research? Journal of Sustainable Tourism, 20(1), 1-7

[16] Utama IGBR. 2017. Pemasaran pariwisata. Yogyakarta: CV Andi Offset.

[17] Nematpour $\mathrm{M}$ and Amin F. 2019.Structural analysis of the tourism impacts in the form of future study in developing countries (case study: Iran).Journal of tourism futures. VOL. 5 NO. 3. pp. 259-282. DOI 10.1108/JTF-05-2018-0028

[18] Cornelisse M. 2019. Sustainability in Ylläs: one focus, various interpretations. Journal of tourism futures. Vol. 6 No. 1. Pp. 40-56,DOI 10.1108/JTF-01-2019-0003 
[19] Thuy VTN and Hoang DPT. 2019. Ecotourists' satisfaction and dissatisfaction: asymmetric effects of service attributes. Journal of Asian Business and EconomicStudies. Vol. 26 No. 2. pp. 189-205. DOI 10.1108/JABES-07-2018-0051

[20] Leaniz PMGD, Angel HC, Raquel GL. 2019. The role of environmental CSR practices on the formation of behavioral intentions in a certifified hotel context Exploring the moderating effect of customer involvement in the buying process. Vol. 23 No. 2. pp. 205-226. DOI 10.1108/SJME-10-2018-0044

[21] Sumardi et al. 2019. Factors Influencing Consumer Decisions in Halal Tourism (Case Study Indonesia and Malaysia). Journal of Technology Management and Business. VOL. 6 NO. 1. PP. 48-55. http://penerbit.uthm.edu.my/ojs/index.php/jtmb

[22] Chauhan V. (2015). Safety and Security Perceptions of Tourists Visiting Kashmir, India In Advances in Hospitality and Leisure. Vol 3: 3-17

[23] Paskova M and Josef Z. 2019. How crucial is the social responsibility for tourism sustainability?Social responsibility journal. VOL. 15 NO. $4 . \quad$ pp. 534-552DOI 10.1108/SRJ-03-2018-0057

[24] Cooper EA. 2019. Cultural centres: a future for cultural Arctic tourism?. Journal of tourism futures. VOL. 6 NO. 1. pp. 57-69, DOI 10.1108/JTF-01-2019-0007

[25] Tresidder R and Emmie LD. 2019. Historic buildings and the creation of experiencescapes: looking to the past for future success. Journal of tourism futures. VOL. 5 NO. 2, pp. 193-201. DOI 10.1108/JTF-04-2019-0034

[26] Hassan S and Mahrous AA. 2019. Nation branding: the strategic imperative for sustainable Market competitiveness. Journal of Humanities and Applied Social Sciences. Vol. 1 No. 2pp. 146-158

[27] Rai S and Jogendra KN. 2019. Hospitality branding in emerging economies: an Indian perspective. Journal of tourism futures. VOL. 5 NO. $1 . \quad$ pp. 22-34. DOI 10.1108/JTF-07-2018-0047

[28] Kara NS and Kezia HM. 2020. Demographic factors and travel motivation among leisure tourists in Tanzania. International Hospitality Review Vol. 34 No. 1. pp. 81-103. DOI 10.1108/IHR-01-2020-0002

[29] Najib et al. 2020. Determinant factors of muslim tourist motivation and attitude in Indonesia and Malaysia. GeoJournallof Tourism and Geosites. vol. 31, no. 3. pp.936-943. DOI $10.30892 /$ gtg.31301-524

[30] Nawi et al. 2019. Brand image and consumer satisfaction towards Islamic travel packages A study on tourism entrepreneurship in Malaysia. Vol. 13 No. 2. pp. 188-202DOI10.1108/APJIE-02-2019-0007

[31] Mkwizu KH. 2019. Digital marketing and tourism: opportunities for Africa. Digital marketing and tourism. Vol. 34 No. 1,pp. 5-12. DOI 10.1108/IHR-09-2019-0015

[32] Bhaduri K and Shivendra P. 2020.Sustainable smart specialisation of small-island tourism countries. Journal of tourism futures. VOL. 6 NO. 2. pp. 121-133. DOI 10.1108/JTF-01-2019-0010

[33] Hughes K and Gianna M 2019. ICT and the future of tourist management. Journal of tourism futures. VOL. 5 NO. 3. pp. 228-240. DOI 10.1108/JTF-12-2018-0072

[34] Mohammed A and Al-swidi A. 2019. The influence of CSR on perceived value, social media and loyalty in the hotel industry. Spanish Journal of Marketing. Vol. 23 No. 3. pp. 373-396DOI 10.1108/SJME-06-2019-0029

[35] Sugiyono. 2018. Metode penelitian manajemen . Bandung: Alfabeta

[36] Euse'bio et al. 2020. The impact of air quality on tourism: a systematic literature review. Journal of tourism futures: 2055-5911 
[37] Ingrit BL. 2019. Literature review: perception and quality of womens life with infertility. Journal of Nursing Current: Vol 7 No 2. 